\title{
Citotoxic Activity of Extracts and Sesquiterpene Lactones from Stachycephalum argentinum
}

\author{
R. Alarcón, C. Vaccarini and V. Sosa \\ Dpto de Química Orgánica, Facultad de Cs Químicas, UNC. Ciudad Universitaria. 5000 Córdoba. Ar- \\ gentina \\ E-mail: roalar@dqo.fcq.unc-edu.ar
}

\begin{abstract}
The extracts and sesquiterpene lactones of S.argentinum were assayed to determine their biological activity on Artemia salina. The most active compound was costunolide (1) with $\mathrm{LD}_{50}=62 \mathrm{ppm}$.
\end{abstract}

\section{Introduction}

Our previous phytochemical study of Stachychephalum argentinum (Asteraceae), revelead the presence of several skeletal types sesquiterpene lactones [1].

In order to explore new natural bioactive products, we started an study of different extracts from $S$. argentinum and some of the sesquiterpene lactones isolated, to determine the citotoxic effect against the microorganism Artemia salina (Leach).

The Brine Shrimp Bioassay determine that compounds with values of $\mathrm{LD}_{50}<1000 \mathrm{ppm}$ could be considered as citotoxic products [2].

\section{Experimental}

Citotoxic Bioassay against Artemia salina was has been described previously [3].

\section{Results and Discussion}

Extracts $\mathbf{B}$ and $\mathbf{C}$ resulted in a marked loss of toxic activity against A. salina. Extract $\mathbf{B}$ showed 60\% lethality and Extract $\mathbf{C}$ showed $33 \%$ lethality at 1000 ppm.

Active compounds against this organism appeared to be costunolide (1) (100\%), 15acetoxycostunolide (2) (60\%) and 8-desoxysalonitenolide (3) (100\%). Compounds such as the eudesmanolides: 4, 5 and $\mathbf{6}$ were inactive against $A$. salina.

The most citotoxic compound was costunolide (1) with $\mathrm{LD}_{50}=62 \mathrm{ppm}$. 
<smiles>[R]C1=CC2CC/C(C)=C/CCC2C1=C</smiles>

$\mathrm{R}$

$\mathrm{CH}_{3}$

$\mathrm{CH}_{2} \mathrm{OAC}$

$\mathrm{CH}_{2} \mathrm{OH}$<smiles>C=C1C(=O)OC2C1CC[C@]1(C)C2C(C)=CC[C@@H]1O</smiles>

(4) santamarin<smiles>C=C1C(=O)OC2C1[C@@H]1CC[C@@H](O)[C@@]2(C)CC1</smiles>

(5) reinosin<smiles>C=C1C(O)CC[C@]2(C)C[C@H]3OC(=O)C(=C)[C@H]3C[C@H]12</smiles>

(6) isotelekin

\section{References and Notes}

1. Lactonas sesquiterpénicas de S. argentinum. IV Simposio Internacional Química de Productos Naturales y sus Aplicaciones,1998, Talca, Chile.

2. $\quad$ Meyer, N.; Ferrigni, N.R.; Putnan, J.E.; et al. Planta Médica 1982, 45, 31.

3. Mc Laughlin, J. L.; Colman-Saizarbitoria, T.; Anderson, J.E. Rev.Venezolana de Quimica 1995, 18, 13 . 